\title{
Influence of Temperature And Storage Duration on Measurement of Prothrombin Time.
}

\author{
1-Prof.Dr.Hasnaa Ahmed Abo- El Wafa,Professor of Clinical Pathology,Faculty of \\ Medicine, Sohag University. 2-Dr. Mohammad Abd Allah Mohammad,Lecturer of \\ Clinical Pathology,Faculty of Medicine, Sohag University.3-Dr. Sherif Abdel Aziz \\ Sayed,Lecturer of Clinical Pathology,Faculty of Medicine, Sohag University. 4- Dr. \\ Amany Abbas Abdel Allah, Lecturer of Clinical Pathology,Faculty of Medicine, \\ Sohag University.5- Mustafa Adel Ahmed, Lecturer of Clinical Pathology,Faculty of \\ Medicine, Sohag University.6- Al Zahra Nasser Mahmoud MohamedResident in \\ Department of Clinical Pathology, Sohag University.
}

\begin{abstract}
Objectives:toinvestigate the sample stabilitywith regard to the temperatureand the storage time and to detect influence of temperature and storage duration on Prothrombin time in citrated plasma.

Patients and Method:This study was carried out in the period between April, 2016 and March, 2017 in the department of clinical pathology, Sohag University Hospital, Sohag, Egypt, during the study period whole blood samples were collected from groups of patients: "43"apparently normal healthy (not receiving anticoagulant) as control (group A) and"43"receiving anticoagulant (17 on warfarin and 26 on heparin) (group B).Each sample of each group will be analyzed forProthrombin time immediately and after $4 \mathrm{hrs}, 8 \mathrm{hrs}$, and $24 \mathrm{hrs}$ of storage.Also each sample will be tested at room temperature $\left(18-22{ }^{\circ} \mathrm{C}\right)$ and at refrigerator temperature $\left(4{ }^{\circ} \mathrm{C}\right)$.
\end{abstract}

Results andConclusion:samples for Prothrombin time were acceptable for analyses up to $24 \mathrm{~h}$ in those not receiving anticoagulant and up to $8 \mathrm{~h}$ in those receiving anticoagulant.

\section{Introduction}

Prothrombin time (PT) measurement is one of routine coagulation tests used to assess pathological alterations of the haemostatic and coagulation systems and guide clinical therapy. Preanalytical factors including specimen collection, transportation, centrifugation, storage and assay method can all affect coagulation testing results (1).

In 1982, it was demonstrated that PT reduction in both normal and patients receiving Coumadin therapy was time and temperature dependent, when samples were collected into borosilicate or siliconized borosilicate tubes, resulting in incorrect adjustment of warfarin dosage (2).

Consequently, the Clinical and Laboratory Standards Institute (CLSI)
H21-A5 recommended that specimens should be analysed within 24-h for PT if stored at RT but did not recommend a storage time for refrigerated storage $\left(2-8 \quad{ }^{\circ} \mathrm{C}\right)$; furthermore, they recommended that $\mathrm{PT}$ samples should not be refrigerated (3).

Many studies have proposed acceptable storage durations for routine coagulation tests at RT and refrigerated temperatures (4). A range of storage times $(2,4,6,8 \mathrm{~h})$ and temperatures $\left(4{ }^{\circ} \mathrm{C}, 25{ }^{\circ} \mathrm{C},>30{ }^{\circ} \mathrm{C}\right)$ have been studied with various criteria for acceptability.

Errors occurring within the preanalytical phases are still the prevailing source of concern. Accordingly, lack of standardized procedures for sample collection, 
SOHAG MEDICAL JOURNAL

Vol. 21 No.3 october 2017
Influence of Temperature And Storage Duration

Al Zahra Nasser Mahmoud Mohamed including patient preparation, specimen acquisition, handling and storage, accounts for most of the errors encountered within the total testing process (1).

Moreover, these guidelines do not clearly stipulate whether samples should be kept as whole blood or plasma and to the best of our knowledge, only few investigations have focused on the sample stability with regard to the temperature and the time before centrifugation. Some earlier studies and the current guidelines indicate that the prothrombin time (PT) might be stable for periods much longer, up to $24 \mathrm{~h}$ $(5,6)$.

\section{Patients and Method:}

\section{Results}

PT samples in control group showed Mean \pm SD $-1.07 \pm 4.03$ with number of samples with $>10 \%$ change was zero at room temperature while Mean \pm SD $1.07 \pm 6.09$ with number of samples with $>10 \%$ change was $3(6.98 \%)$ at $4 \mathrm{C}^{\circ}$ after 4 hours of storage. After 24 hours storage Mean \pm SD was $1.72 \pm 3.78$ with number of samples with $>10 \%$ change was $1(2.33 \%)$ at room temperature while at $4 \mathrm{C}^{\circ}$ Mean $\pm \mathrm{SD}$ was $2.08 \pm 10.45$, with number of samples with $>10 \%$ change was $8(18.60 \%)$.

According to that the acceptable time for storage of samples of PT from control group not receiving anticoagulant was 24 hours whether at room or $4 \mathrm{C}^{\circ}$ temperature.

While PT samples in group receiving anticoagulant showed Mean \pm SD 2.60 \pm 5.81 with number of samples with $>10 \%$ change was $4(9.30 \%)$ at room temperature while Mean \pm SD $0.84 \pm 4.03$ with number of samples with $>10 \%$ change was $2(4.65 \%)$ at 4 $\mathrm{C}^{\circ}$ after 4 hours of storage.

According to that the acceptable time for storage of samples of PT from group receiving anticoagulant was 8 hours whether at room or $4 \mathrm{C}^{\circ}$ temperature.

Table (1): Percentage change in PT measurement over time of studied population in control group. 
SOHAG MEDICAL JOURNAL

Vol. 21 No.3 october 2017
Influence of Temperature And Storage Duration Al Zahra Nasser Mahmoud Mohamed

\begin{tabular}{|c|c|c|c|c|}
\hline PT & At room temperature & $\begin{array}{l}\text { Number }(\%) \text { of } \\
\text { samples with }>10 \% \\
\text { change }\end{array}$ & At $4 \mathrm{C}^{\circ}$ & $\begin{array}{l}\text { Number }(\%) \text { of } \\
\text { samples with } \\
>10 \% \text { change } \\
\end{array}$ \\
\hline $\begin{array}{l}\text { At } 4 \text { hours } \\
\text { Mean } \pm \text { SD } \\
\text { Median } \\
\text { (range) }\end{array}$ & $\begin{array}{l}-1.07 \pm 4.03 \\
-0.89(-8.45-8.00)\end{array}$ & 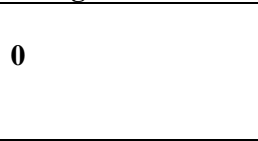 & $\begin{array}{l}1.07 \pm 6.09 \\
0.89(-16.26-12.12)\end{array}$ & $3(6.98 \%)$ \\
\hline $\begin{array}{l}\text { At } 8 \text { hours } \\
\text { Mean } \pm \text { SD } \\
\text { Median } \\
\text { (range) } \\
\end{array}$ & $\begin{array}{l}-1.36 \pm 4.29 \\
-0.79(-11.38-5.74)\end{array}$ & $2(4.65 \%)$ & $\begin{array}{l}1.53 \pm 6.65 \\
2.65(-16.26-11.81)\end{array}$ & $5(11.63 \%)$ \\
\hline $\begin{array}{l}\text { At } 24 \text { hours } \\
\text { Mean } \pm \text { SD } \\
\text { Median } \\
\text { (range) }\end{array}$ & $\begin{array}{l}1.72 \pm 3.78 \\
0.96(-3.82-10.08)\end{array}$ & $1(2.33 \%)$ & $\begin{array}{l}2.08 \pm 10.45 \\
2.33(-30.08-36.61)\end{array}$ & $8(18.60 \%)$ \\
\hline $\begin{array}{l}\text { Acceptable } \\
\text { time }\end{array}$ & 24 hours & & 24 hours & \\
\hline
\end{tabular}

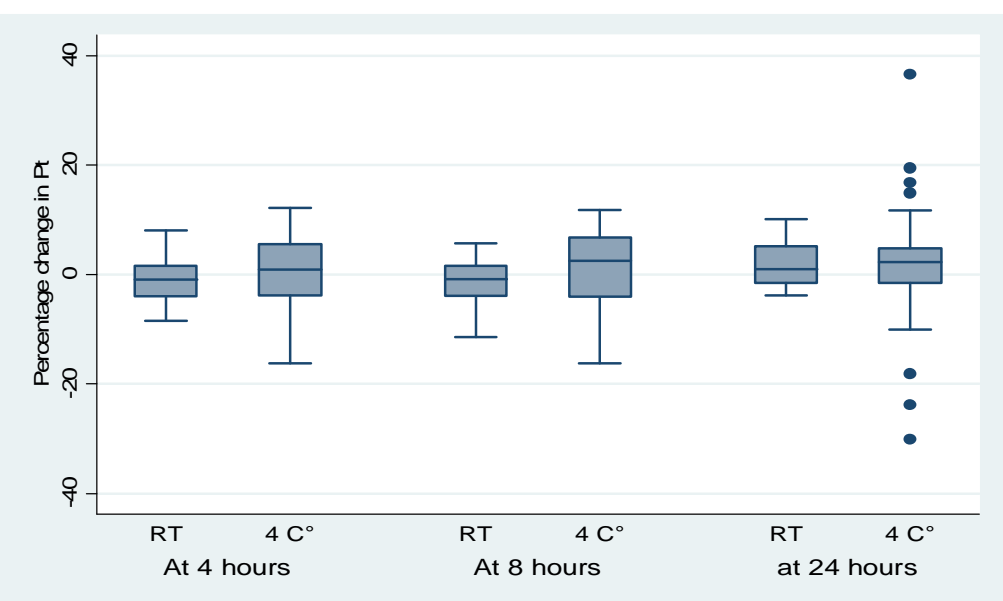

Figure (1): Percentage change in PT measurement over time of studied population in control group.

Table (2): Percentage change in PT measurement over time of studied population in Anticoagulant group.

\begin{tabular}{|c|c|c|c|c|}
\hline PT & $\begin{array}{l}\text { At room } \\
\text { temperature }\end{array}$ & $\begin{array}{l}\text { Number }(\%) \text { of } \\
\text { samples with } \\
>10 \% \text { change }\end{array}$ & At $4 \mathrm{C}^{\circ}$ & $\begin{array}{l}\text { Number }(\%) \text { of } \\
\text { samples with }>10 \% \\
\text { change }\end{array}$ \\
\hline $\begin{array}{l}\text { At } 4 \text { hours } \\
\text { Mean } \pm \\
\text { SD } \\
\text { Median } \\
\text { (range) }\end{array}$ & $\begin{array}{l}2.60 \pm 5.81 \\
0.73(-9.47: 20.14)\end{array}$ & $4(9.30 \%)$ & $\begin{array}{l}0.84 \pm 4.03 \\
0.66(-8.38: 12.35)\end{array}$ & $2(4.65 \%)$ \\
\hline $\begin{array}{l}\text { At } 8 \text { hours } \\
\text { Mean } \pm \\
\text { SD } \\
\text { Median } \\
\text { (range) }\end{array}$ & $\begin{array}{l}3.55 \pm 4.21 \\
3.31(- \\
10.53: 12.28)\end{array}$ & $3(6.98 \%)$ & $\begin{array}{l}5.29 \pm 4.45 \\
4.65(-8.42: 15.07)\end{array}$ & $4(9.30 \%)$ \\
\hline $\begin{array}{l}\text { At } 24 \text { hours } \\
\text { Mean } \pm \\
\text { SD } \\
\text { Median } \\
\text { (range) }\end{array}$ & $\begin{array}{l}27.39 \pm 51.40 \\
14(1.24: 303.68)\end{array}$ & $33(76.74 \%)$ & $\begin{array}{l}19.10 \pm 9.80 \\
17.39(1.86: 52.72)\end{array}$ & $36(83.72 \%)$ \\
\hline $\begin{array}{l}\text { Acceptable } \\
\text { time }\end{array}$ & 8 hours & & 8 hours & \\
\hline
\end{tabular}


SOHAG MEDICAL JOURNAL

Vol. 21 No.3 october 2017
Influence of Temperature And Storage Duration

Al Zahra Nasser Mahmoud Mohamed

\section{Discussion}

In coagulation studies, the diagnosis of coagulation disorders and monitoring of anticoagulant therapy usually depend mainly on PT values (7).

In general, coagulation tests should be carried out as soon as possible after collection of the blood samples.(Wang B) demonstrated that after as little as 1 $h$, samples stored at RT may show significant differences compared with baseline results, although these differences would not have a significant impact on clinical diagnosis or treatment decisions. Thus, a statistically significant difference need not be the same as a clinically relevant difference(12).

Identification of a clinically relevant difference is difficult because there is no consensus defining clinical relevance. Most studies use percentage change (Kemkes-Matthes) decided that sporadic changes exceeding $15 \%$ in more than $10 \%$ of samples defined clinical relevance(15).(Adcock et al.,) defined a change by $>15 \%$ as a clinically relevant difference while (Geest-Daalderop et al.,) proposed that if the number of individuals with a greater than $10 \%$ percentage change was less than $25 \%$ of the total sample number, the effect should be termed moderate and clinically relevant $(3,16)$.

(Wang B) defined a change $>10 \%$ in PT as significant. There are no guidelines defining acceptable percentage preanalytically for coagulation assays(12).We therefore used the same approach as (Zürcher) and defined a percentage change $>10 \%$ from baseline results as a clinically relevant difference(11).
In our study we found that the acceptable time for storage of PT ,in those who didn't receive anticoagulant, whether at room or $4{ }^{\circ} \mathrm{C}$ temperature was up to 24 hours, as the number of samples with $>10 \%$ change was more than $25 \%$ of the sample. While in those who received anticoagulant (with prolonged PT) we found that the acceptable time for storage of PT whether at room or $4{ }^{\circ} \mathrm{C}$ temperature was up to 8 hours, as the number of samples with $>10 \%$ change was more than $25 \%$ of the sample.

This findings were partly consistent with A previous study carried out by (Adcok et al.,) on plasma samples reported different findings; they exposed plasma to three different types of storage conditions (RT, refrigerator and frozen) (3).

At both RT and Following refrigerated storage, (Wang Xiao) and (Rao) found that PT results were increased with duration of storage $(9,7)$. (Salvagno et al.,) found that PT results decreased initially before increasing(10).(Kemkes-Matthes)

found that PT results after 8 and $24 \mathrm{~h}$ storage were all statistically different when compared with baseline results at RT. They further demonstrated that the differences exceeded the analytical quality specifications for desirable bias following $24 \mathrm{~h}$ storage(15).

Earlier studies vary in the acceptable time interval they identify. (Wang Xiao) found PT could be analysed up to $8 \mathrm{~h}$ following collection at $4{ }^{\circ} \mathrm{C}$ and up to $4 \mathrm{~h}$ at $25^{\circ} \mathrm{C}$. Wang B found PT samples were acceptable up to $8 \mathrm{~h}$ following collectionat $\operatorname{RT}(9,12)$. 
SOHAG MEDICAL JOURNAL Vol. 21 No.3 october 2017
Influence of Temperature And Storage Duration

Al Zahra Nasser Mahmoud Mohamed
In our study variation in measurement of PT in control samples was insignificant up to 24 hours in those not receiving anticoagulant while variations were significant at 24 hours with more than $25 \%$ of samples had more than $10 \%$ change in measurement in those receiving anticoagulant.

The variation in the PT values during the first few hours of storage was too small. Although statistically significant differences were observed for PT tests after $24 \mathrm{~h}$ and $8 \mathrm{~h}$ at both room temperature and refrigerator, the differences might not alter the clinical interpretation of the results.

Our findings are partially comparable to those reported by (Koepke et al.,) and (Neofotistos et al.,) who concluded that no changes were noted in PT up to $6 \mathrm{~h}$, and no changes in PT up to $8 \mathrm{~h}$ respectively. $(13,14)$

\section{Conclusion}

To conclude, we found that samples for PT were acceptable for analyses up to $24 \mathrm{~h}$ in those not receiving anticoagulant and up to $8 \mathrm{~h}$ in those receiving anticoagulant.

\section{References}

1. Lippi G., Guidi G.C., Mattiuzzi C. \&Plebani M. (2006) Preanalytical variability: the dark side of the moon in laboratory testing. Clinical Chemistry and Laboratory Medicine 44, 358-365.

2. Palmer RN and Gralnick HR (1985): Inhibition of cold-promoted activation of the prothrombin time. Studies of new siliconised borosilicate collection tubes in normals and patients receiving warfarin.Am J Clin Path 83: 492-494.

3. Adcock DM, Hoefner DM, KottkeMarchant K, Marlar RA, Szamosi DI, Warunek DJ. (2008). Collection, transport, and processing of blood samples for testing plasma-based coagulation assays and molecular hemostasis assays.
Approved guideline: 5th ed. (H21-A5). Wayne, PA: Clinical and Laboratory Standards Institute.

4. Mohammed Saghir, S. A., Al-Hassan, F. M., Alsalahi, O. S., Abdul Manaf, F. S. \&Baqir, H. S. (2012). Optimization of the storage conditions for coagulation screening tests. J Coll Physicians Surg Pak 22, 294-297.

5. Brigden M.L., Graydon C., McLeod B. \&Lesperance M. (1997) Prothrombin time determination. The lack of need for a discard tube and 24-h stability. American Journal of Clinical Pathology 108, 422426.

6. NCCLS (2003).National Committee for Clinical Laboratory Standards.Collection, Transport and Processing of Blood Specimens for Coagulation Testing and General Performance of Coagulation Assays.Approved Guideline H21-A4, 3rd edn.NCCLS, Wayne, PA.

7. L.V. Rao, A.O. Okorodudu, J.R. Petersen and M.T. Elghetany., (2000).ClinicaChimicaActa300 (P 13 21).

8. Adcock D, Kressin D, Marlar RA.(1998). The effect of time and temperature variables on routine coagulation tests. Blood CoagulFibrinol; 9:463-470.

9. Wang, X., Ma, J. Z. H. \&Hao, Z. L. (2002). Influence of storage time of PT and APTT at different temperature. Journal of Hebei Medical University 23, 108-109.

10. Salvagno GL, Lippi G, Montagnana M, Franchini M, Poli G, Guidi GC(2009). Influence of temperature and time before centrifugation of specimens for routine coagulation testing. Int $\mathrm{J}$ Lab Hematol; $31: 462-467$.

11. Zürcher M, Sulzer I, Barizzi G, La"mmle B, Alberio L (2008). Stability of coagulation assays performed in plasma from citrated whole blood transported at ambient temperature. ThrombHaemost; 99:416-426. 
SOHAG MEDICAL JOURNAL

Vol. 21 No.3 october 2017
Influence of Temperature And Storage Duration

Al Zahra Nasser Mahmoud Mohamed
12. Wang B, Guo W, Pan B. Influence of storage time at room temperature on routine coagulation tests. Chin J Lab Med2011;34:595-7.

13. Koepke JA, Rodgers JL, Ollivier MJ.(1975). Pre-instrumental variables in coagulation testing. Am J Clin Pathol;64:591-6.

14. Neofotistos D, Oropeza $M$, HsinTsao C.(1998) Stability of plasma for add on PT and aPTT tests. Am J Clin Pathol;109:758-63.

15. Kemkes-Matthes B, Fischer R, Peetz D (2011).Influence of 8 and 24-h storage of whole blood at ambient temperature on prothrombin time, activated partial thromboplastin time, fibrinogen, thrombin time, antithrombin and D-dimer. Blood CoagulFibrinolysis;22:215-20.

16. Van Geest-Daalderop JH, Mulder AB, Boonman-de Winter LJ, Hoekstra MM, van den Besselaar AM.( 2005). Preanalytical variables and off-site blood collection: influences on the results of the prothrombin time/international normalized ratio test and implications for monitoring of oral anticoagulant therapy. Clin Chem;51:561-8. 
SOHAG MEDICAL JOURNAL

Vol. 21 No.3 october 2017
Influence of Temperature And Storage Duration Al Zahra Nasser Mahmoud Mohamed

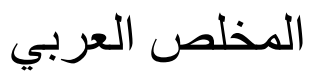

زمن البروثرومبين عبارة عن اختبارمن اختبار ات التخثر الروتينية المستخدمة لتقييم التغيرات

المرضية لنظم تخثر الدم والتي تستخدم لتوجيه طرق العلاج اللازم. ان عوامل ما قبل التحليل

و التي قد تؤثر علي نتائج الاختبارات تثمل جمع العينات، النقل، الطرد المركزي، التخزين

وطرق الفحص. المعهد المعني بمعايير الاختبارات والتحاليل اكد علي ان العينات يجب ان ينم

فحصها وتحليلها في خلال ع س ساعة لزمن البروثرومبين لو تم تخزينها في درجة حرارة

الغرفة ولكنه لم يحبذ وقت تخزيني لدرجات حر ارة من Y Y درجة سيلزية علاوة علي ذلك فإنه

فضل عدم وضع عينات زمن البروثرومبين في درجة حرارة المبرد. العديد من الدراسات

وضعت مدي للزمن التخزيني لعينات اختبارات تخثر الدم الروتينية في درجة حر ارة الغرفة

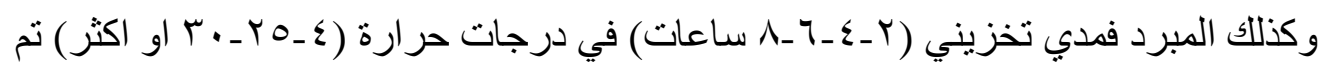

در استها مع نتائج مرضية الي حد ما. تم ايضا فحص عو امل ماقبل التحليل مثل العو امل

الميكانيكية و التي تتعرض لها العينات كطرق النقل، نم فحصها وتبين انها تؤثر الي حد كبير

علي زمن البروثرومبين بعض الدر اسات الاولية و التوجيهات الحديثة اشارت الي ان زمن البروثرومبين قث بظل مستقر الفترة ليست اكثر من ع باعة 